\title{
WINTER SOUTHERN WIND FLOW AND AIR POLLUTION EPISODES OVER ATHENS, GREECE
}

\section{P. A. KASSOMENOS \\ S. LYKOUDIS \\ G. KALLOS}

Received: $4 / 3 / 99$

Accepted: 22/6/99
University of Athens,

Department of Applied Physics, Laboratory of Meteorology, Panepistimioupolis, Building PHYS-V, GR-15784, Athens, Greece.

\section{ABSTRACT}

The greater area comprising the Attica peninsula and the Saronic Gulf is greatly influenced by various local circulation types. During winter months, moderately high air pollutants concentrations are observed when the prevailing condition is either stagnant or a weak southern flow. The case studied in this paper regards an episode that occurred in mid-December. This episode is characterized by very weak pressure gradient over Greece, and very little change in wind speed and direction with height, without the precedence of exceptionally strong warm advection in the lower troposphere during the days before the episode. This episode was not characterized by very high air pollution values, a rather common feature during December, that even though it presents one of the highest episode frequencies, the observed values are not high enough to require the enforcement of restrictive measures.

KEYWORDS: air pollution, winter episodes, local flows, regional flow, southern flow, RAMS model, Athens.

\section{INTRODUCTION}

The degradation of the atmospheric environment has significantly intensified during the last decades in the cities of the modern societies. In Athens this phenomenon became significant since the end of the 70s. Today is mainly a photochemical pollution problem involving pollutants such as $\mathrm{NO}_{\mathrm{X}}, \mathrm{O}_{3}$, VOCs, etc. High air pollutant concentrations have quite often been measured in Athens in the past years. Those concentrations often lay above the limits adopted by the European Union (EU) and the World Health
Organization (WHO) (Kassomenos et al., 1999). The city complex of Athens - Piraeus Suburbs is located in a narrow valley closed by mountains on the three sides and open to the sea on its south side. Some crossings exist between the mountains that link the valley and the rest of the mainland. The complexity of the terrain characteristics of Attica and especially the Athens Basin leads to the generation of complex atmospheric circulation types. The interactions between these circulation types affect the air pollution dis- 
persion and diffusion patterns significantly, making them a subject difficult enough to study.

Several researchers have dealt with the air pollution problem in the Athens Basin area in the past. More specifically, they have focused on the correlation between certain mesoscale circulation types and increased air pollution levels. Sea breeze was considered, by the vast majority of researchers, to be associated with the occurrence of air pollution episodes (Helmis at al., 1987; Melas at al., 1998, among others). Other researchers were mainly concerned with other local circulation types, such as upslope/downslope winds, associating them with pollution episodes or synoptic conditions related to episodes (Kallos et al., 1993; Kassomenos et al., 1998a). The position of the mountain crossings and in general the terrain characteristics of the area result in the generation of complex flows within the Attica peninsula - Saronic Gulf - Southern Evoikos Gulf system (Mousiopoulos et al., 1997). Extensive experiments were performed in the past in order to thoroughly study the pollution problem in the area (Asimakopoulos et al., 1992; Ziomas, 1998; Kambezidis et al., 1998). An assessment of the air quality conditions over a 15 -year period has been attempted by Kassomenos et al. (1998 a,b). All these studies carried out so far, have outlined a set of important factors that determine air quality over the Athens Basin.

As can be seen from the above, the researchers' attention has been focused on air pollution episodes during summer and the transitional seasons that are predominantly related to the sea breeze phenomenon. Analysis of the episodes for a 12-year period (1983-1995) (Kassomenos et al., 1998a), though, revealed that more than one third of the episodes occur during winter, while one sixth of the total number of episodes occurs during December. In this paper

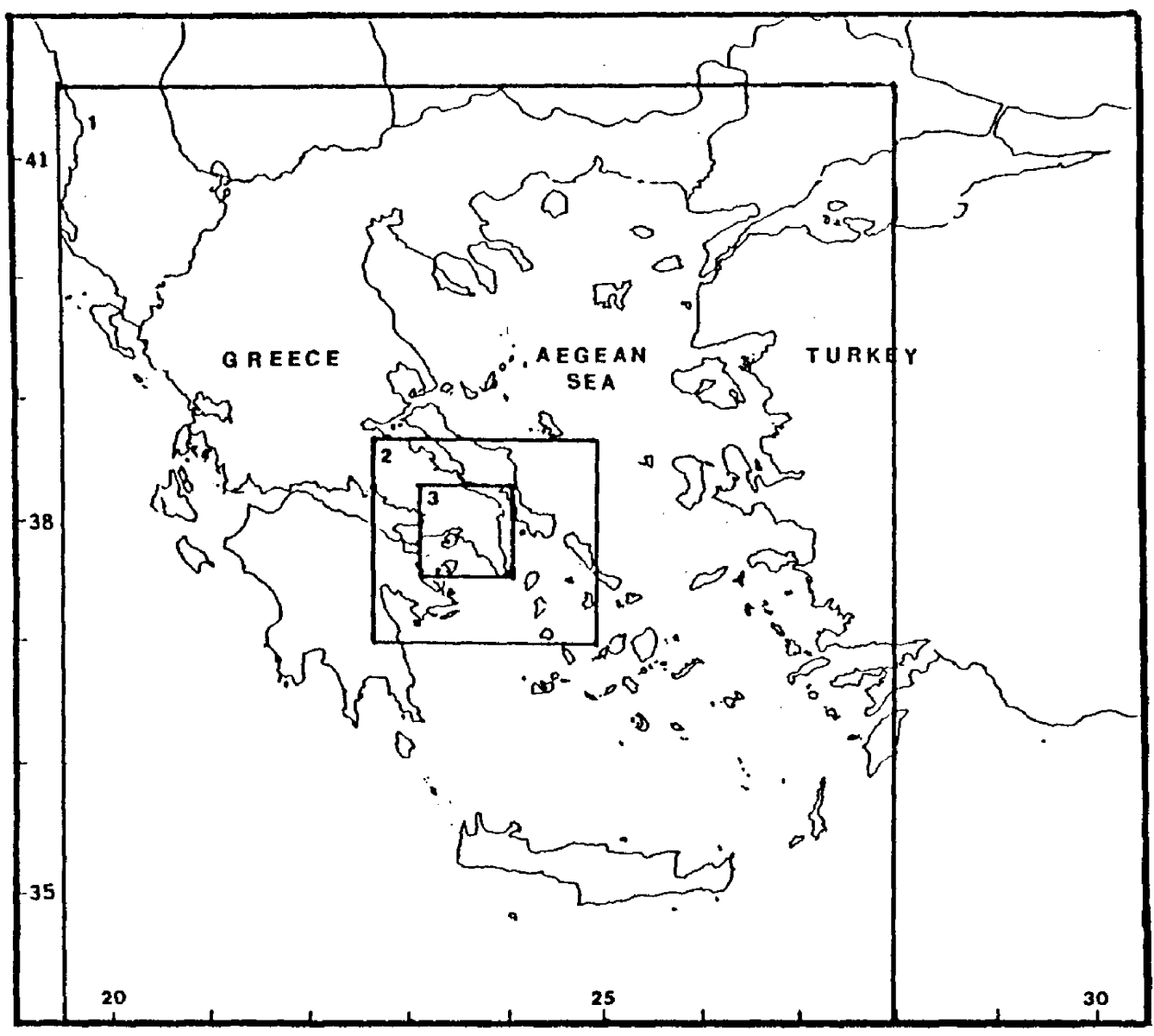

Figure 1. The position of the 3 domains, in which the simulations were performed, in the greater Northeastern Mediterranean area 
an attempt has been made to study the winter air pollution problems in the area of Athens.

The second chapter of this paper contains a brief description of the models and the data used. An extended analysis of the meteorological conditions prevailing during the examined episodes is presented in chapter 3 . The fourth chapter presents the results of the simulations, while the last chapter contains the conclusions drawn from this case study.

\section{DATA- SOFTWARE USED}

Description of the models used

For the simulation of the meteorological conditions required for this study the CSU-RAMS model was used (Pielke et al., 1992). This model is a 3-D, prognostic non-hydrostatic atmospheric model based on the primitive equations of movement, energy, continuity, and mass and water vapor preservation.

Some of the main features of this model are:

- Two-way interaction between the overlaying grids. Infinite number of overlaying grids either horizontally or vertically.

- Terrain following surfaces with Cartesian, or polar stereographic horizontal coordinates.

- Cloud microphysics parameterization.

- Parameterization of the short and long wave radiative transfer through the atmosphere, with and without clouds.

- Parameterization of the surface layer with a prognostic model for soil and vegetation.

The dispersion-diffusion model used has been developed by McNider (1981). This model utilized as input, the output of the mesoscale atmospheric model described above. It is a Langrangian dispersion-diffusion model in which the movements of discrete elementary air mass particles (representing air pollutants released from one or more sources) are tracked around the simulation area.

Input data

For the meteorological fields analysis the meteorological model was applied using three overlaying grids. The outer overlaying grid included mainland Greece, the Aegean Sea and the western part of Asia Minor, using $16 \times 16 \mathrm{~km}^{2}$ grid cells. The analyzed area covered $752 \times 832 \mathrm{~km}^{2}$. The intermediate overlaying grid consisted of $4 x 4$ $\mathrm{km}^{2}$ grid cells covering a total area of $228 \times 196 \mathrm{~km}^{2}$ extending from west of Corinth to east of Andros and from south of Hydra to north of Chalkis. The inner overlaying grid was analyzed into $2 \times 2 \mathrm{~km}^{2}$ grid cells including a total area of $86 \times 86 \mathrm{~km}^{2}$, extending from west of Megara to east of Makronisos and from south of Attica to north of Marathon (Figure 1). For the vertical analysis a telescopic vertical grid was used, extending from the surface to the height of around $11 \mathrm{~km}(27 \mathrm{ver}$ tical layers). The simulation started at 02:00 Local Time (LT) and went on for 36 hours with a time step of $50 \mathrm{~s}$ for the outer grid (the time steps for the other two grids are automatically set). The topography data were extracted, using interpolation, from $5^{\prime}$ latitude x $5^{\prime}$ longitude NCAR database into a $16 \times 16 \mathrm{~km}^{2}$ grid. For the Southern Greece region the topography data were extracted from maps with a resolution of $1000 \mathrm{~m}$. Using this topography the land-sea distribution and the land use were obtained for each grid cell. The model version used was the non-hydrostatic one with zero-gradient boundary conditions for the outer grid and two-way interaction between the overlaying grids for the other two grids, regarding the lateral boundaries, while regarding the top, a fixed height along with a cushioning layer was adopted. The domain layout was such that permitted the onset of the simulation using just the detailed radiosonde data of the National Meteorological Service (NMS) from Elliniko Airport at 02:00 LT. A uniform sea surface temperature was used throughout the domain equal to $289 \mathrm{~K}$, obtained from averaging of the sea surface temperatures in the greater analyzed area (data from the Greek Hydrographic Service). Land use data, such as vegetation index, urban areas, type of soil, etc., were extracted from SPOT satellite images. Roughness length over land was estimated for each grid cell according to land use. Additional data, such as soil thermal capacity, density and moisture, were obtained from the literature.

\section{METEOROLOGICAL DESCRIPTION OF THE POLLUTION EPISODE CASE STUDY (DECEMBER 13-14, 1989)}

The case presented here is the episode that took place on December 13-14, 1989. On December 11 the surface winds blew from NE directions, relatively strong at noon, and the sky 


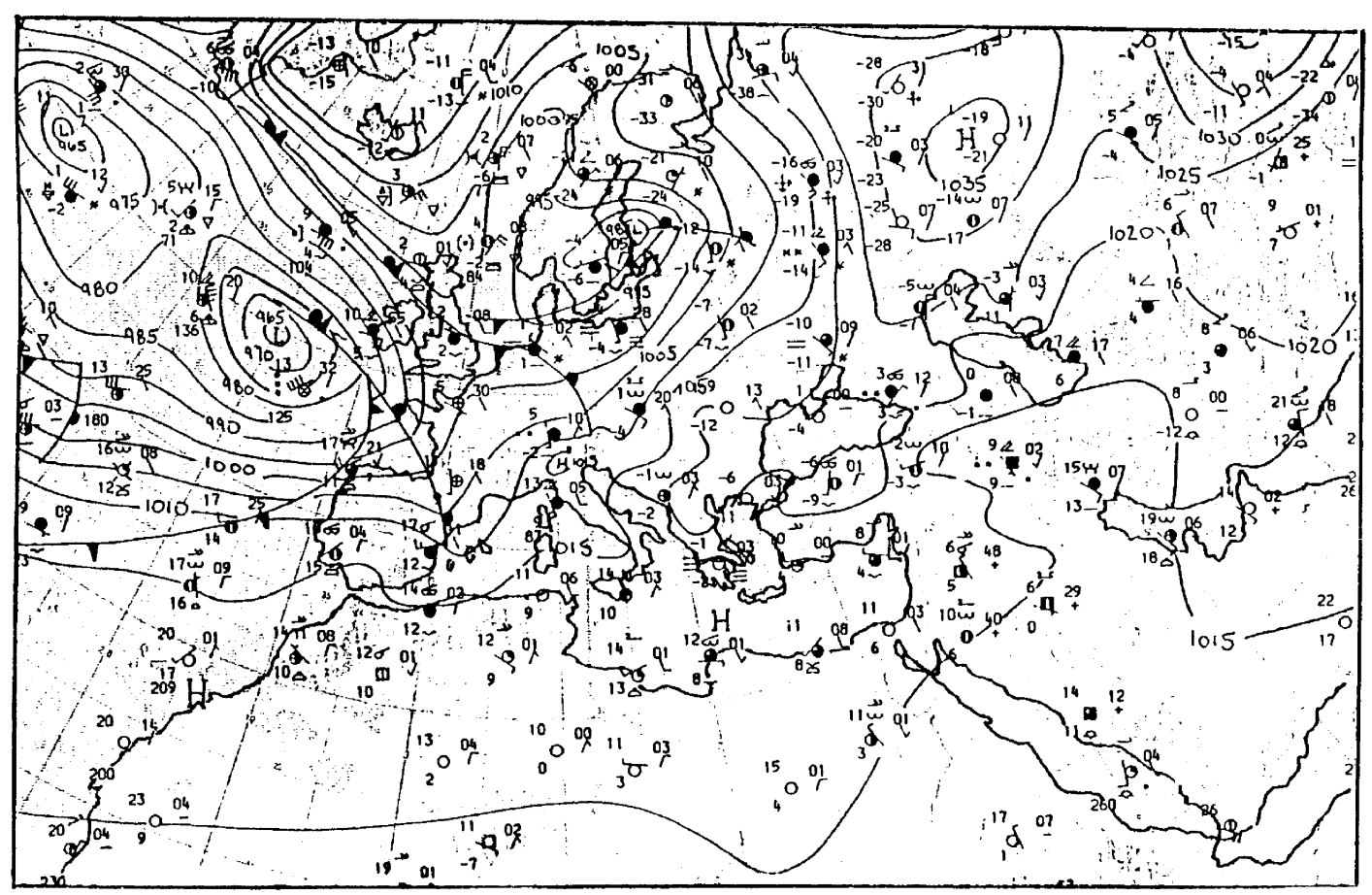

Figure 2. Synoptic surface map for December 13th, 1989 at 00.00 UTC

was completely overcast. An anticyclone centered over the Black Sea covered the entire Balkan Peninsula. High pressures were observed at surface as well as aloft (500 hPa). A low-pressure system had passed over the area the previous day and caused some precipitation. Those days, and especially on December 10, there seemed to exist cold advection in the lower troposphere. The day after (December 12) an anticyclone covered the entire Balkans and the Eastern Mediterranean area. The sky was clear while the surface winds blew from $\mathrm{W}$ or SW directions at noon, and from $\mathrm{N}$, very weak, at night. The pressure gradient was very weak over Greece (about $1 \mathrm{~h} \mathrm{~Pa} / 1000 \mathrm{~km}$ ). On December 13, the first day of the episode, the surface pressure was rather high over the entire Balkans and western Asia Minor. The surface wind blew from southern directions, weak at noon and from NW at night (Figure 2). The pressure field up to $700 \mathrm{hPa}$ was smooth while the wind blew from NW directions, weak. The same weather conditions also prevailed the day after (December 14) when the pressure gradient and the wind weakened even more. The winds aloft were weak or moderate (never exceeding $8 \mathrm{~m} / \mathrm{s}$ ) from $\mathrm{W}$ or $\mathrm{NW}$ directions and the pressure field was smooth. The day after the surface wind blew weak from $\mathrm{N}$ or NW directions, while the pressure gradient intensified over the Aegean. The winds aloft became stronger over the Aegean. The thermohygrometric structure of the lower troposphere during the episode (Figure 3) shows that on December 13 a stable stratification of sufficient depth has been formed near the surface, where, as a result of the observed warm advection between the $900 \mathrm{hPa}$ and $800 \mathrm{hPa}$ layers during the day, the lower troposphere becomes stable. The warm advection expanded the following days. During the night of December 13, a surface temperature inversion was formed, with a depth less than $200 \mathrm{~m}$ that dissolved the next morning. At noon, an elevated inversion was formed at a height of about $1000 \mathrm{~m}$, with less than $200 \mathrm{~m}$ in depth and slightly more than $1^{\circ} \mathrm{C}$ in strength. The soil was wet enough due to the precipitation that occurred on December 11, and there was no potential for the development of a deep boundary layer since, on the one hand, the insolation was not intensive this time of the year, and, on the other hand, a great portion of it was transformed into latent heat flux. The winds over the entire Athens Basin blew from variable directions throughout the day. The mixing height during the night did not exceed $150 \mathrm{~m}$ for December 13 and 
14 , while during the day it was fairly restricted (from 300 to $500 \mathrm{~m}$ ). The meteorological conditions described above lead to the accumulation of high air pollutants concentrations that did not, however, require restrictive measures to be imposed (Figure 4). The episode ends on December 15 when a strong pressure gradient is established over Greece.

\section{SIMULATION RESULTS}

\subsection{Flow fields analysis}

For the flow field simulation the meteorological model described above was used. This simulation showed that during the night and early morning of December 13 the winds over the mountainous Greek mainland were blowing weak from NW directions. In the greater Attica area the winds over the sea were weak blowing from variable directions, while over land they weakened even more. A weak northern flow can be seen along the Southern Evoikos Gulf. Over the mountains the downslope winds still existed since the sun had just risen. This time of the year the sun rises about two hours later than the summer and the sunshine duration is limited (a little more than 9 hours in December compared to about 15 hours in the summer).

As the day advanced, while the winds were still weak to moderate over the Greek Mountains, the regional scale flow began to go around Peloponnese and then moved towards the Attica and Saronic Gulf area. This NW flow was stronger during noon hours, and was due to the fact that the regional scale flow was directed around Peloponnese. Meanwhile the winds over the central and eastern Aegean remained very weak since the pressure gradient over Greece was also weak. Over the greater area of Attica and Saronic Gulf, a weak SW flow appeared as the day advanced, while the winds over the Basin blew from southern directions. Insolation is fairly low this time of the year. Therefore the upslope winds observed were both significantly weakened and delayed to appear. The precipitation that

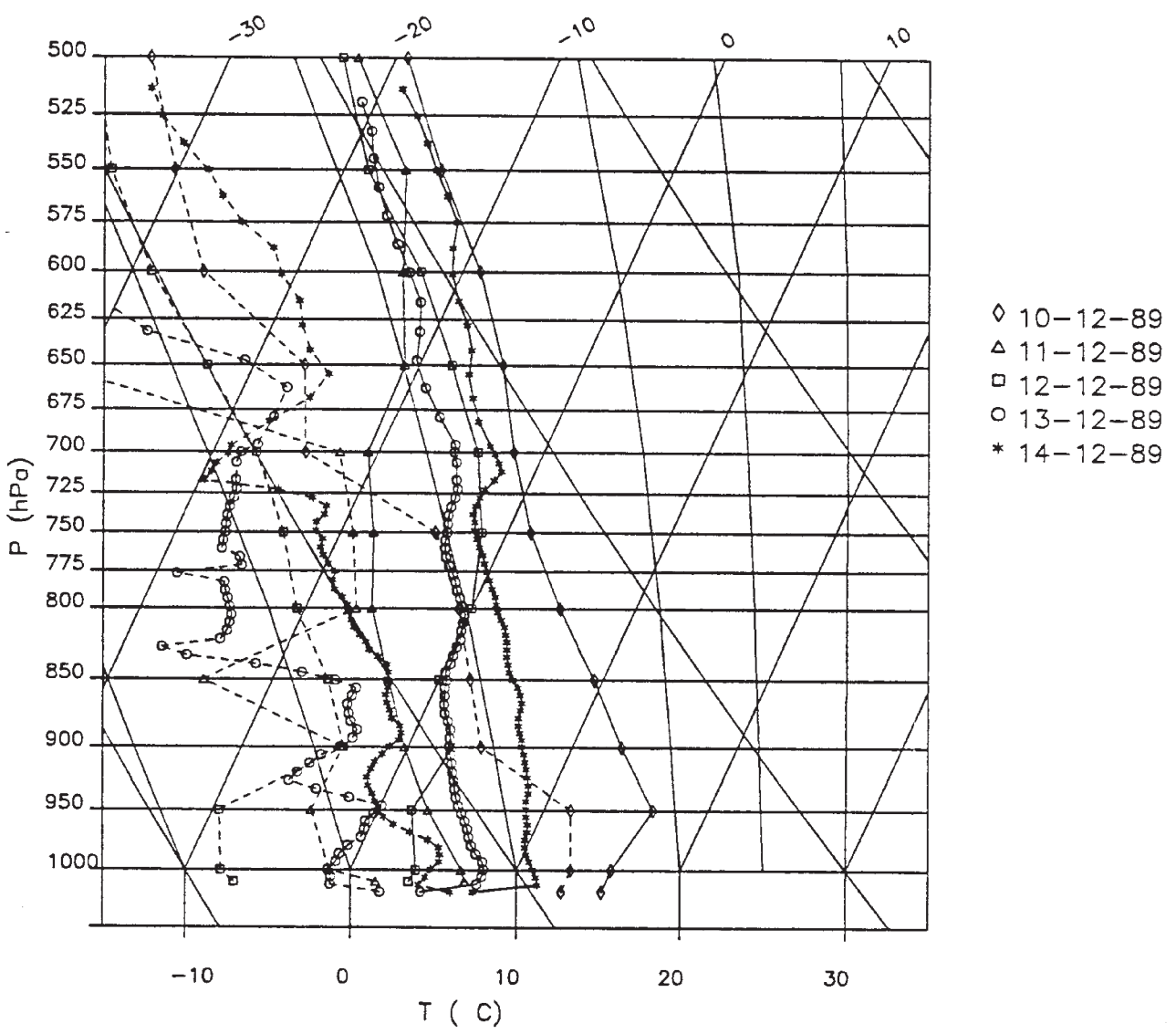

Figure 3. SKEW-T diagram for 02.00 LT for the period 10-14/12/89 
occurred some days before, did not allow, to a significant extent, the vertical development of the, either way shallow due to the season, boundary layer. Over the Mesogia Plain the winds blew from eastern directions owing to canalization of the northern flow along the Southern Evoikos Gulf (Figure 5). The southern flow continued during the afternoon hours over the Attica area. The winds were weak, blowing from southern directions throughout the Basin, while a part of the southern flow from the Saronic Gulf was separated, entering the Mesogia Plain through the Kalivia crossing.

The southern flow over the Southern Evoikos restrains the previous hours' weak northern flow over the area. During this time of the year the sea is still warm enough compared to the already cold land, resulting to a temperature difference not especially large, even during noon (about $3{ }^{\circ} \mathrm{C}$ ). So the establishment of a sea breeze mechanism during this season is, even though possible (Karapiperis and Katsoulis, 1977), troublesome, since the main reason for the development of such a mechanism is the existence of a large temperature gradient between land and sea. The winds blowing from southern directions over the Basin, as they were measured at various stations and forecast by the model for some hours of this day, seem to be attributable rather to the $\mathrm{N}-\mathrm{NW}$ flow, as a result of the diversion of the regional scale circulation by the large topographical obstacle of Peloponnese, than to the land-sea temperature difference. The synoptic flow disturbance caused by the local circulations did not seem to extend beyond $700 \mathrm{~m}$ above surface.

Later in the afternoon, as the sun began to set the regional scale flow diversion around Peloponnese gradually weakened, and the winds over Greece turned to western directions. The winds over the Basin were very weak, blowing from variable directions. Over Saronic Gulf the southern flow was gradually suspended, while an eastern surface flow appeared between Hymettus and Aegina, over the Saronic. The vertical extent of this disturbance did not exceed $500 \mathrm{~m}$.

Later at night, the winds were weak blowing

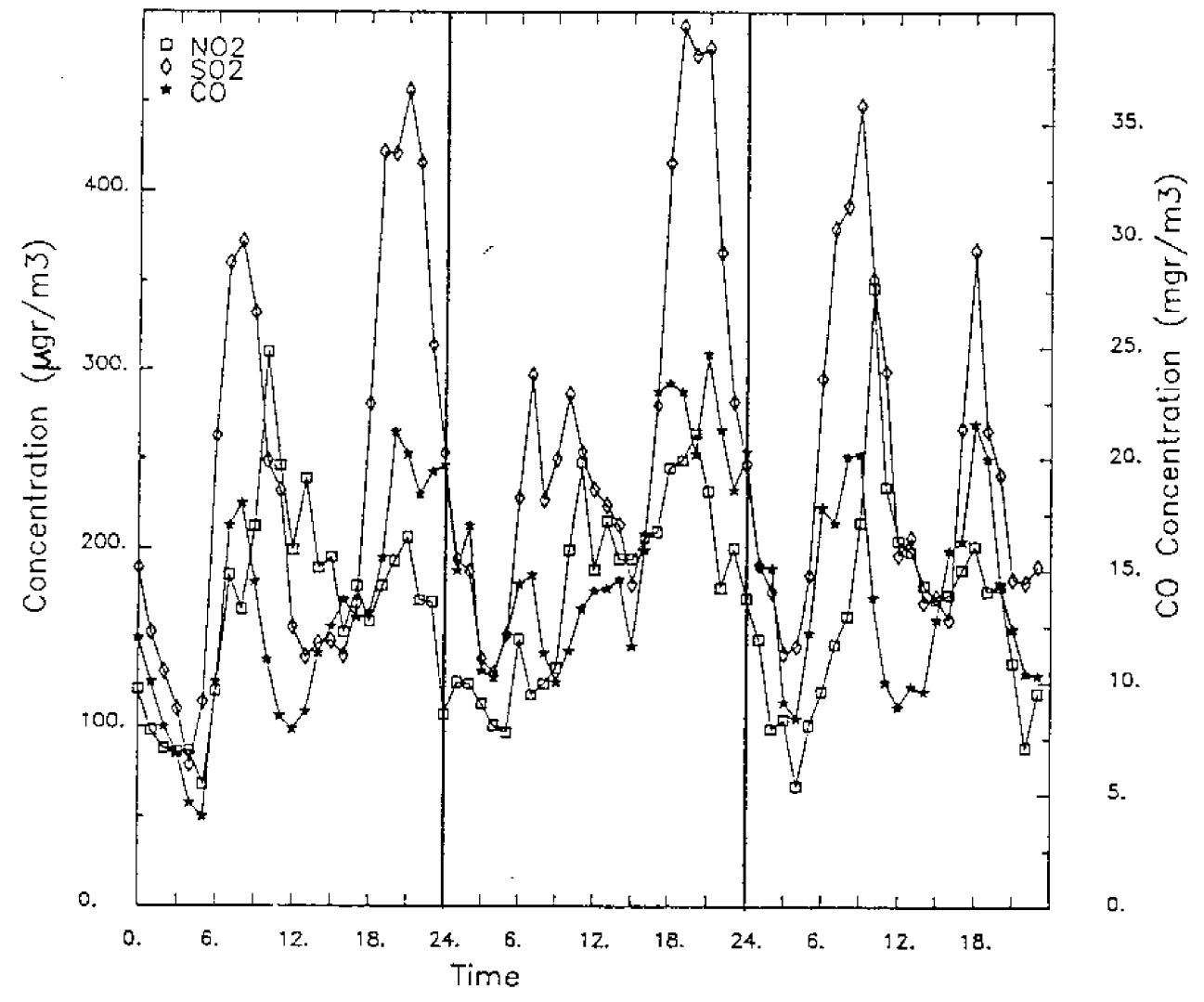

Figure 4. $\mathrm{CO}, \mathrm{SO}_{2}$ and $\mathrm{NO}_{2}$ observed concentrations in the center of Athens for 12-14/12/89 


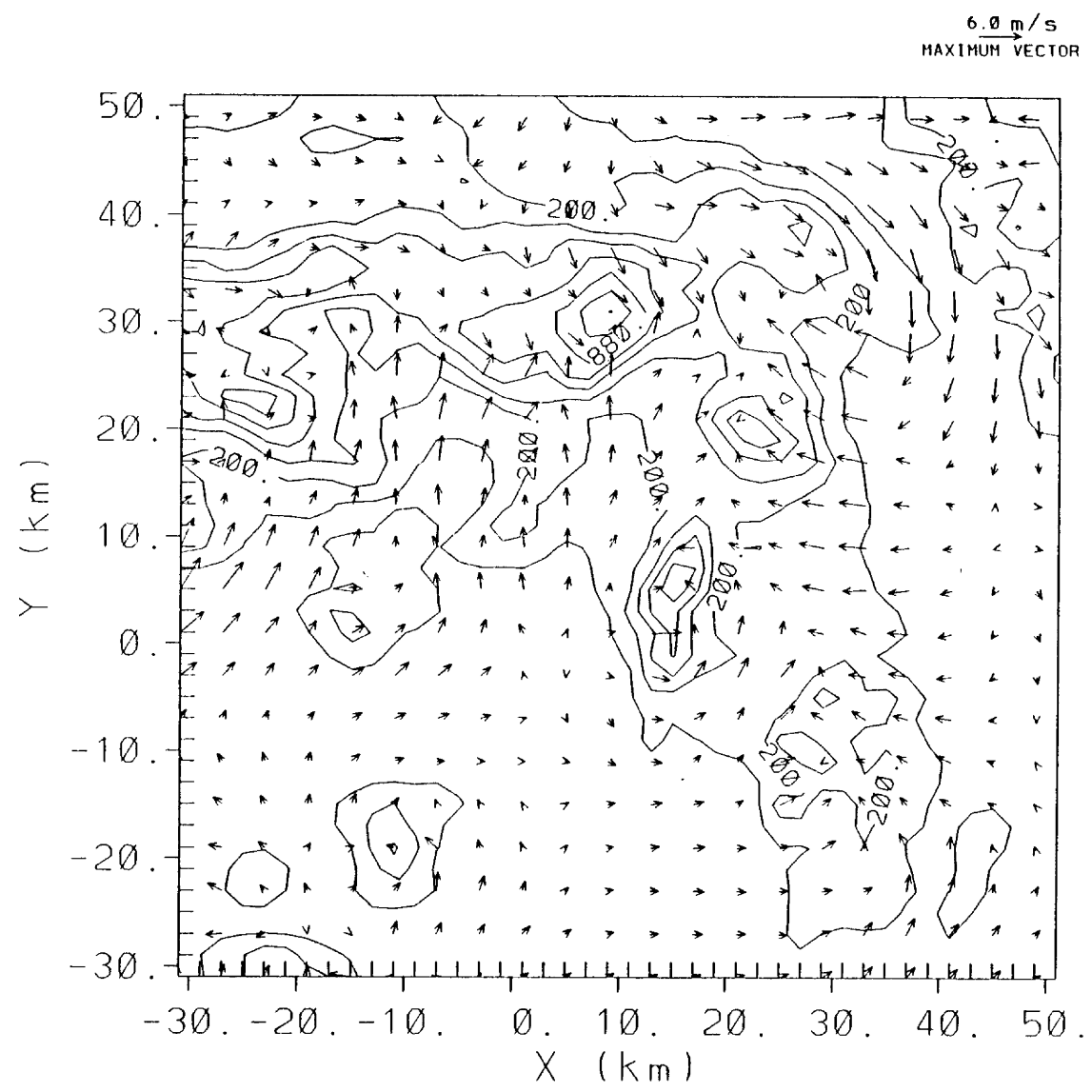

Figure 5. Flow field in the inner domain at 14.00 LT of $13 / 12 / 89$ at $20 \mathrm{~m}$ above ground

from variable directions over the Basin at surface level, while weak valley and downslope winds were also observed. Over the Saronic the winds generally blew from $\mathrm{W}$ to $\mathrm{NW}$ directions.

4.2 Some characteristics of the dispersiondiffusion of air pollutants over the system Attica peninsula - Southern Evoikos Gulf-Saronic Gulf

In order to study certain characteristics of the dispersion-diffusion of air pollutants released from various sources in the greater Athens area, the dispersion-diffusion model described above was used.

For the investigation of the behavior of air pollutants released from elevated point sources located in the greater Attica area, three sources were selected. Two of them are located at the west of the Athens Basin (Ag. Theodoroi (AGT) and Aspropirgos (ELDA) refineries), and one source is located at the west edge of the Athens Basin coastline (Power plant in Keratsini (KER)).
This source is used as indicative as it has been withdrawn since 1981, yet still remains as a backup unit. For the AGT plant no source was available and certain indicative values were used instead (Table 1). Emission for all sources commenced at 05:00 LT and was continuous (plume), releasing elementary air masses equivalent to the air pollutant mass released by a source in $10 \mathrm{~s}$. These air masses represent an inert air pollutant as $\mathrm{SO}_{2}$.

Nevertheless, in the greater Thriassion and Attica areas, a large number of small industries and factories are also operating as well as other anthropogenic activities distributed over vast areas (Elefsis, Piraeus harbor, Elaionas, etc.) releasing an undefined but significant amount of air pollutants, especially during certain hours of the day. These sources can be considered as area sources. To investigate the contribution of those sources to the overall pollution of the Attica area an instantaneous release (puff) of numerous (e.g. 


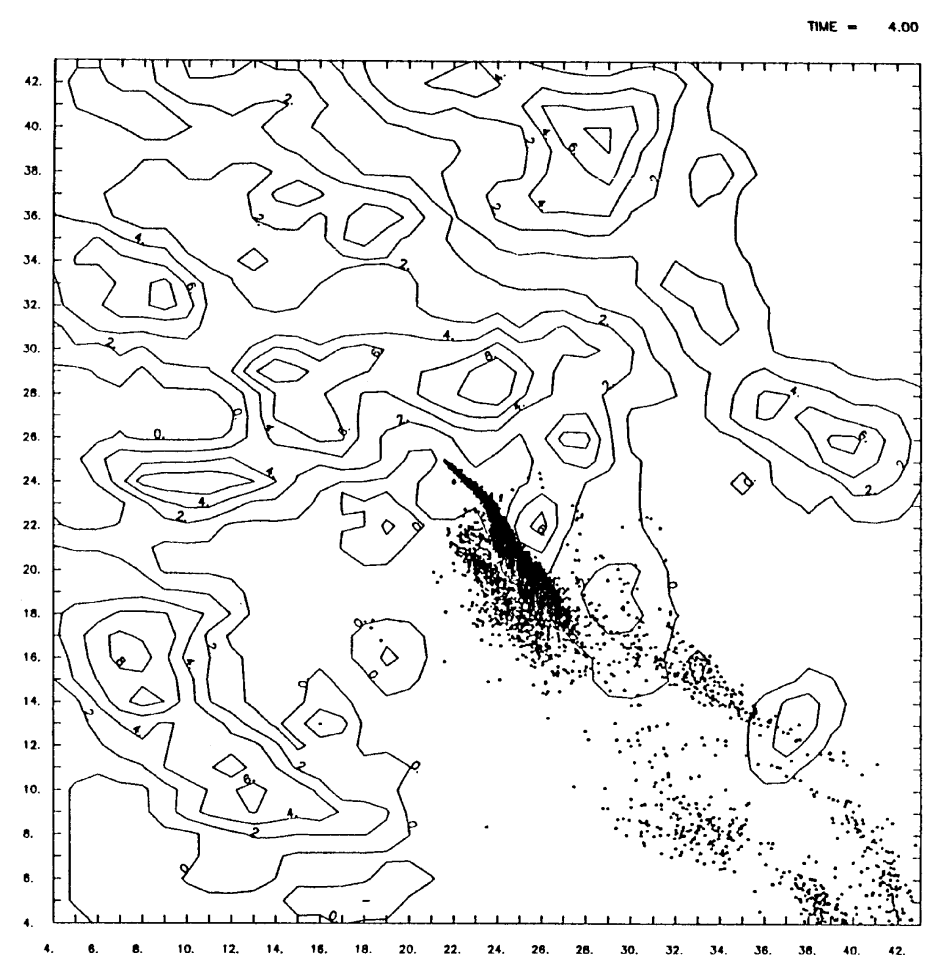

Figure 6. Positions of air pollutants released from ELDA tall stack at 04.00 LT of 14/12/89

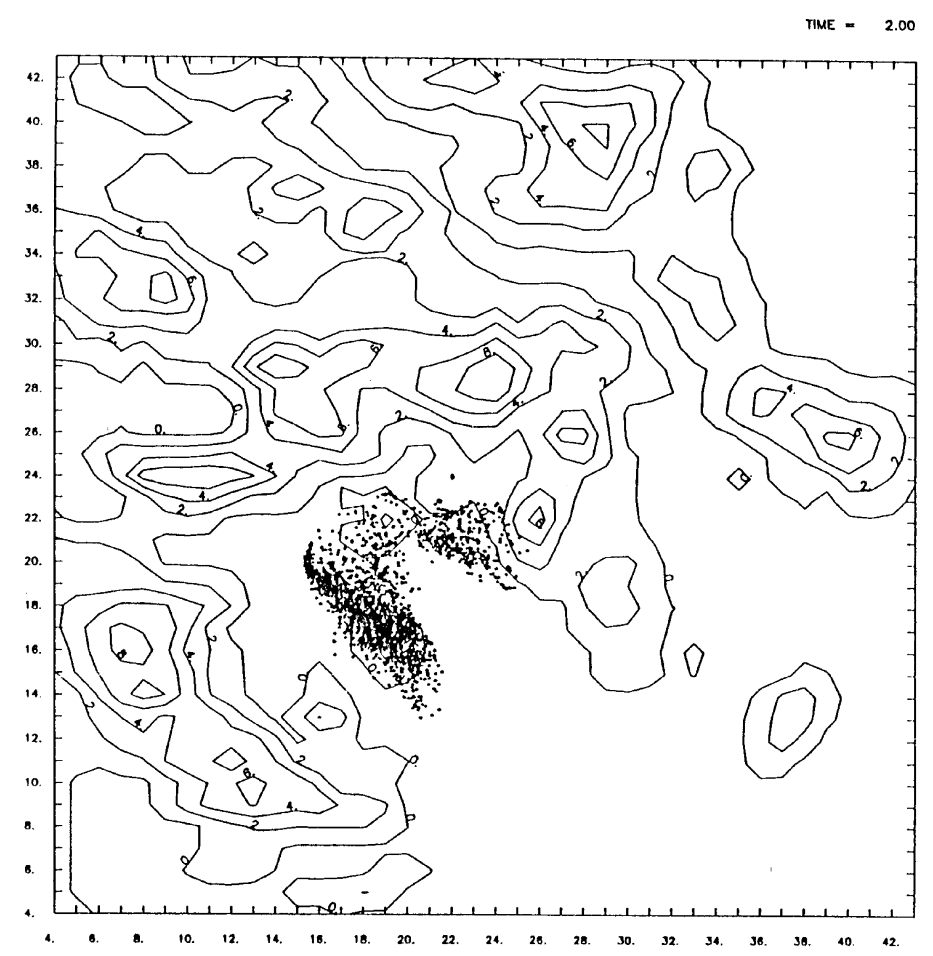

Figure 7. Positions of air pollutants released from Elefsis area source at 02.00 LT of 14/12/89 
3000) elementary air masses was considered, corresponding to air pollutants in various regions, and various hours of the day and their spatial and temporal behavior was monitored. The dimensions of each area source used are $2 \times 2 \mathrm{kmxkm}$. Pollutants advancing along a rather thin line means that transport exists without significant diffusion (emission under stable conditions). Movement around an extended area means that favorable dispersion conditions exist. This usually happens when the emissions occur inside the atmospheric boundary layer during the day or when the wind presents a shift in direction, with time. Finally, advancement along a rather thick line means that the movement happens in areas with strong winds where turbulent mixing prevails over thermal mixing.

\subsubsection{Impact from sources located west of} Athens

From the elevated sources located in Western Attica, the AGT refinery was used. The effective height of this stack varied between 200 and $350 \mathrm{~m}$ during the simulation. Air pollutants released from this stack, both during day and night hours, were dispersed over the western Saronic and Aegina, where they remained for several hours. Initially, the air pollutants moved above the boundary layer, under stable conditions, and their advancement along a relatively wide line, showed that turbulent was more important than thermal mixing, but late in the afternoon, as the boundary layer developed, some of the air pollutants moved under unstable conditions inside the boundary layer and were dispersed in a relatively large area over the western Saronic. During the night the air pollutants followed the same path, under stable conditions. Anyway there is no indication of air pollution transport over Thriassion Plain and Eastern Saronic since the southwestern flow that appeared certain hours of the day and was capable of pushing the pollutants towards those regions, was very weak and shallow.

From the elevated sources situated in the Thriassion Plain, the two stacks of ELDA were used for the simulation (Table 1). The effective height of the lower stack was less than $200 \mathrm{~m}$ throughout most of the day, and in any case did not exceed $250 \mathrm{~m}$. As the day progressed, air pollutants released early in the morning, due to the small effective height of the stack, moved under unstable conditions inside the boundary layer, and were slowly dispersed over either the Aegaleo Mountain or the Thriassion Plain, and over the western suburbs of Athens at first and over the entire Basin later on. As the boundary layer developed vertically the air pollutants were dispersed aloft. The winds over the Basin were blowing weak and from variable directions, and resulted in dispersed air pollutants remaining over the area for a long time. During the night, released air pollutants were slowly dispersed over the eastern Thriassion Plain, and through the crossings connecting those two regions, over the western Athens Basin. Due to the weak winds the pollutants remained over the region for many hours. Later on, as the sun rose, upslope winds began to appear while the boundary layer extended vertically. Therefore, air pollutants released later in the morning as well as those remaining, dispersed towards the Athens Basin and the Saronic Gulf. The effective height of the tall ELDA stack ranged between $450-500 \mathrm{~m}$ through the simulation. Initially, air pollutants after their release moved for several hours under stable conditions above the boundary layer. Late in the afternoon air pollutants released by this stack began to disperse over a wider area of the Basin. The difference with the behavior of the air pollutants released from the short stack is apparent, since air pollutants released by it were dispersed over a much wider area as a result of their prolonged movement inside the boundary layer. As the day progressed and the vertical extent of the boundary layer was limited, air pollutants released from the tall stack moved under stable conditions, especially during the night (Figure 6). It must be noted that the density of "particles" showed in this and the remaining figures does not represent the concentration of the pollutants at the ground level and they must be handled as inert air masses describing the flow conditions in the studied area. The day after, air pollutants released later, when the boundary layer was sufficiently developed - usually in late afternoon, were dispersed over a more extended area.

In order to investigate a possible impact of the Elefsis industrial zone on the pollution of the greater Athens area, this was considered as an area source. This area source released instantaneously a large number of elementary air masses corresponding to various air pollutants for differ- 
Table 1. Stacks and area sources data for the simulations

\begin{tabular}{|l|c|c|c|c|}
\hline Station & $\begin{array}{c}\text { Stack } \\
\text { Height } \\
(\mathrm{m})\end{array}$ & $\begin{array}{c}\text { Stack diameter } \\
(\mathrm{m})\end{array}$ & $\begin{array}{c}\text { Exit } \\
\text { velocity } \\
(\mathrm{m} / \mathrm{s})\end{array}$ & $\begin{array}{c}\text { Exit temperature } \\
(\mathrm{K})\end{array}$ \\
\hline Keratsini (KER) & 155 & 5.5 & 21 & 483 \\
\hline ELDA A & 30 & 3.2 & 2.12 & 444 \\
\hline ELDA B & 120 & 4.4 & 9.2 & 483 \\
\hline Ag.Theodoroi (AGT) & 75 & 3.0 & 5 & 400 \\
\hline Elefsis area source & 10 & 2000.0 & 2 & 300 \\
\hline Athens area source & 10 & 2000.0 & 2 & 300 \\
\hline
\end{tabular}

ent hours of the day. Air pollutants released in the morning after sunrise, were dispersed initially over the Thriassion Plain and slowly moved towards western Athens and Piraeus, since their movement took place inside the boundary layer under unstable conditions and the winds were weak. The low intensity of the wind resulted in air pollutants remaining over the Basin for several hours, while the vertical development of the boundary layer transported them to higher altitudes and they were dispersed over larger areas. The movement of some of the air pollutants during late afternoon along the eastern coast of the Basin showed that they followed the wind field some hundred meters above surface after they ascended following the development of the boundary layer. Air pollutants released at night from this area departed slowly from it moving under stable conditions, due to the surface inversion observed at night owing to the weak northern winds blowing over the Elefsis area. The vast majority of these air pollutants moved towards the Islands of Salamis and Aegina, while a few were transported towards Piraeus (Figure 7). Throughout the whole night air pollutants remained dispersed over the Saronic Gulf, moving very slowly and at low altitudes to the south. Subsequently, they left the area early in the afternoon of the day after.

\subsubsection{Impact from sources within the Basin}

For the case study of the winter episode examined herein the Keratsini stack effective height has been evaluated to be 500 to $600 \mathrm{~m}$ throughout the simulation. As a result the release occurred above the boundary layer for the greater part of the night and the day, and assisted by the northwest winds the movement was parallel to the east- ern coastline of the Attica basin over the Saronic Gulf for many hours. It is obvious that the air pollutants movement took place under stable conditions for the greatest part of the day. Only at noon, when the boundary layer had reached its maximum extent, there is a tendency for air pollutants to disperse over a wider area of the Saronic. Nevertheless, the weak southwest flow towards the Basin that occurred at that time, had small vertical amplitude and could not transport air pollutants towards the Basin.

In order to study the possible contribution to the Basin's pollution from sources within it, an extended area source was considered, situated approximately in the area of Elaionas, with instantaneous releases of a great number of elementary air masses corresponding to air pollutants, during certain hours of the day. Air pollutants released at 08:00 LT were dispersed towards the eastern side of the Basin moving at low altitudes under unstable conditions, since the inversion had dissolved and the weak winds delayed their removal. The air pollutants released in the morning were removed after 18:00 LT towards the Saronic Gulf. The air pollutants released at 12:00 LT initially moved under unstable conditions, gaining some altitude due to the fact that the south weak flow over the Basin was shallow, and consequently they too moved along the eastern coastline and were removed from the Basin within a few hours. Their dispersion height was relatively limited but nevertheless higher than the height in which the air pollutants, released in the morning, moved. The air pollutants released at 20:00 LT moved, during most of the night, towards the Saronic Gulf, due to weak north winds blowing over the Basin. After being transported over the Saronic Gulf they remained there 
TIME $=3.00$

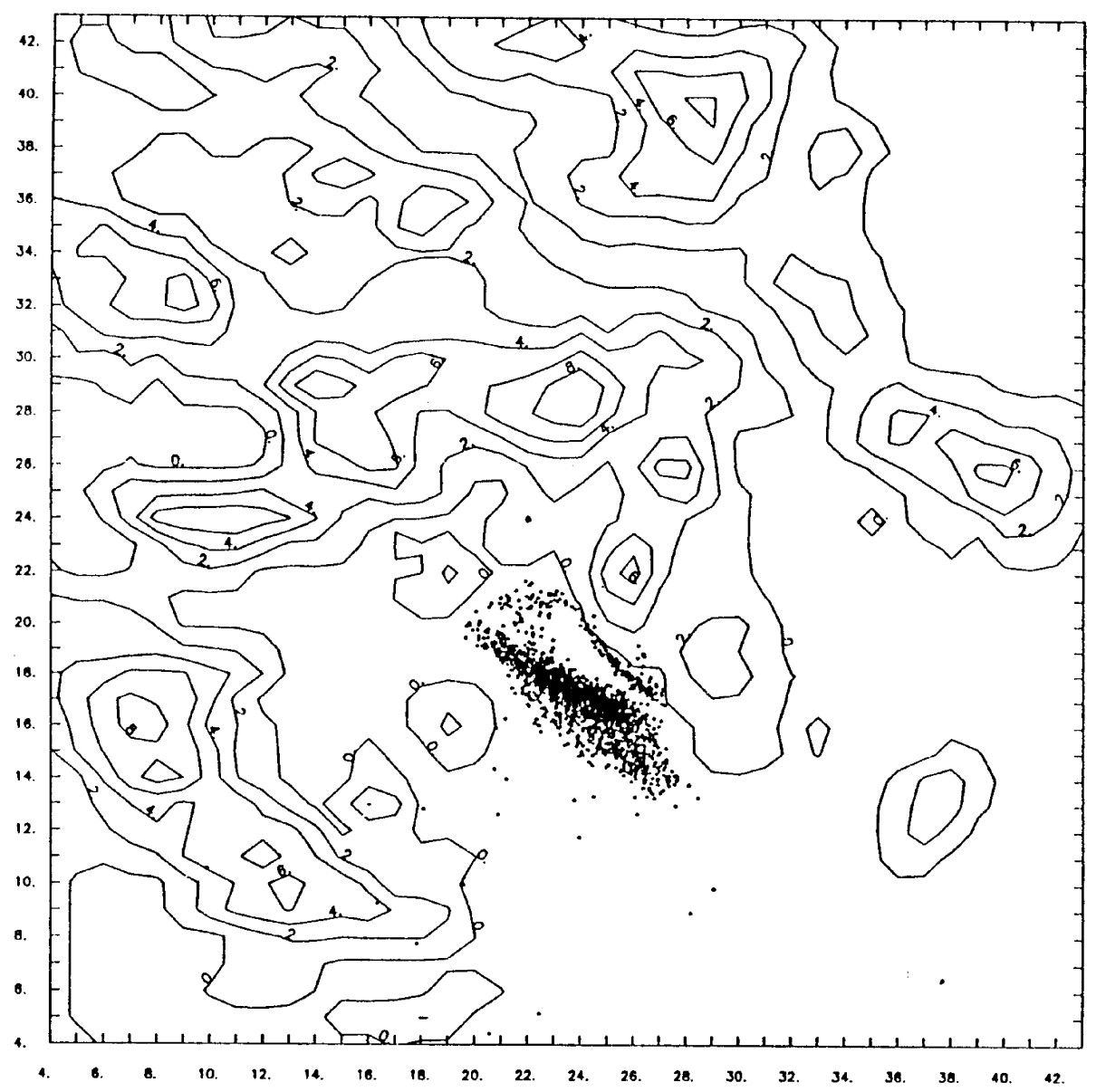

Figure 8. Positions of air pollutants released from Elaionas area source at 03.00 LT of 14/12/89

for most of the night, since their dispersion was very slow due to the weak winds and the very small vertical extent of the mixing height over the sea (Figure 8). These air pollutants, even though they moved at relatively low altitudes and remained over the Saronic Gulf for the greater part of the night, slowly drifted to the south and were removed.

\section{CONCLUSIONS}

The objective of this work was to investigate the diurnal variation of the meteorological fields during a winter air pollution episode characterized by a very weak pressure gradient at the surface, and stable stratification of the lower troposphere, without the occurrence of intense warm advection the days preceding the episode. During the episode the air pollutants concentrations were not high enough to require restrictive measures.
This type of episode is very common during winter in Athens.

From the simulation it was apparent that the southern flow observed over the Attica Basin was due mainly to the deviation of the regional scale flow around Peloponnese, rather than the establishment of a winter sea breeze, because of the small land-sea temperature difference during this season of the year. These flows are also very common during winter.

From the comparative study of two different height ELDA stacks at Thriassion Plain, it was deduced that air pollutants released from the lower stack were being dispersed for many hours over the Athens Basin during daytime, due the delay of the boundary layer development and the weak winds. On the contrary, air pollutants released from the tall stack were delayed to disperse over the Basin, since their release took 
place above the boundary layer, most of the time. During nighttime, air pollutants released from the low stack were widely dispersed over the Thriassion Plain as well as over the Athens Basin, since their release took place inside the mixing layer, while those released from the tall stack moved above the boundary layer thus not affecting the Basin.

The main conclusion of the releases from the area source located at Elefsis as well as from the one inside the Basin, was that the air pollutants released during morning hours were transported or remained for several hours above the Basin, since the winds were not strong enough to remove them quickly and the boundary layer delayed to develop.

On the contrary, air pollutants released during night, way before sunrise, moved, assisted by the winds, towards the Saronic, where they remained for a long period, since the mixing height during the night was especially shallow over the sea. These pollutants were slowly removed to the south and were not brought back to the $\mathrm{N}$. Saronic Gulf and the Athens Basin.

\section{REFERENCES}

Asimakopoulos, D. N., D. Deligiorgi, C. Drakopoulos, C. Helmis, K. Kokkori, D. P. Lalas, D. Sikiotis and C. Varotsos, 1992: An experimental study of nighttime air pollutant transport over the complex terrain of Athens, Atm. Env., 26B, 59-71.

Helmis, C. G., D. N. Asimakopoulos, D. N. Deligiorgi and D. P. Lalas, 1987: Observations of sea breeze fronts near the shoreline. Bound. Layer. Meteorol., 38, 395-410.

Kallos, G., P. Kassomenos and R. Pielke, 1993: Synoptic and mesoscale circulations associated with air pollution episodes in Athens, Greece. Bound. Layer Meteorol., 63, 163-184.

Kambezidis, H. D., D. Weidauer, D. Melas and M. Ulbricht, 1998: Air quality in the Athens basin during sea breeze and non sea breeze days using laser remote sensing technique. Atm. Env., 32, 2173-2182.

Karapiperis, L. and Katsoulis B., 1977: Contribution to the study of sea breeze in Athens area, during winter. Bull. Hell. Meteor. Soc., 2, 1-18.

Kassomenos, P., H. A. Flocas, A. N. Skouloudis, S. Lykoudis, V. Asimakopoulos and M. Petrakis, 1998a: Relationship of air quality indicators and synoptic scale circulation at $850 \mathrm{hPa}$ over Athens, during 1983-1995. Env. Tech., 19, 13-24.

Kassomenos, P., H. A. Flocas, S. Lykoudis and A. N. Skouloudis, 1998b: Spatial and temporal characteristics of the relationship between air quality status and mesoscale atmospheric circulation over an urban Mediterranean basin. The Sc. of Total Env., 217, 37-57.

Kassomenos, P., A. N. Skouloudis, S. Lykoudis, H. Flokas, 1999: “Air quality indicators” for uniform indexing of atmospheric pollution over large metropolitan areas. Atm. Env., 33, 1861-1879.

McNider, R. T., 1981: Investigation of the impact of topographic circulations on the transport and dispersion of air pollutants. Ph.D. Dissertation, University of Virginia, Charlottesvile, Virginia.

Melas, D., I. Ziomas, I. Klemm and C.S. Zerefos, 1998: Anatomy of the sea breeze circulations in urban Athens under weak large-scale ambient winds. Atm. Env., 32, 2223-2237.

Moussiopoulos, N., P. Sahm, K. Karatzas, S. Papalexiou and A. Karagiannidis, 1997: Assessing the impact of the new Athens airport to urban air quality with contemporary air pollution models. Atm. Env.,31, 14971511.

Pielke, R.A., W.R. Cotton, R.L. Walko, C.J. Tremback, W.A. Lyons, L.D. Grasso, M.E. Nicholls, M.D. Moran, D.A. Wesley, T.J. Lee and J.H. Copeland, 1992: A comprehensive meteorological modeling system, RAMS. Meteorol. Atmos. Phys., 49, 69-91.

Ziomas, I. C, 1998: The Mediterranean campaign of photochemical tracers transport and chemical evolution (Medcaphot-Trace)- An outline. Atm. Env., 32, 2045-2053. 